plate was employed as the counter electrode.

After deposition, the electrolyte was replaced with a fresh buffer solution which had been deoxygenated by passing nitrogen, and the potential of the electrode was swept with the scanning rate of $0.21 \mathrm{~V} / \mathrm{min}$ from $-1.1 \mathrm{~V}$ to $-0.1 \mathrm{~V}$ vs. SCE, when the deposits on the electrode were stripped and the SV-gram was recorded.
In this step, the counter electrode was an SCE. Bath temperature was $25^{\circ} \mathrm{C}$. The area of the second peak was proportional to the concentration of gallium(III) in the deposition bath. Linear range was from $1.8 \times$ $10^{-5} M$ to $3 \times 10^{-4} M$ of gallium. The relative deviations were $7.2 \%$ or less.

(Received Nov. 27, 1972)

\title{
海 水中のセレンのけい光定量
}

\author{
平木敬三，由井 収，平山宏，西川泰治*，重松恒信**
}

(1972 年 11 月 7 日受理)

\begin{abstract}
セレン(IV) は 2,3-ジアミノナフタレンと $\mathrm{pH} 1$ で反応し，4,5-ベンゾピアセレノールを生成し， シクロへキサン，トルエンなどの有機溶媒に抽出される. これらの抽出有機相を $375 \mathrm{~nm}$ (シクロへキ サン）あるいは $380 \mathrm{~nm}$ (トルェン）で励起するとそれぞれ $520 \mathrm{~nm}, 538 \mathrm{~nm}$ にけい光中心波長を有す るけい光を発する.このけい光を利用した微量セレン(IV) のけい光定量法の各種条件を検討し, これ を用いて海水中のセレンを定量する方法を確立した，海水中のセレンの捕集には，水酸化鉄を用いる共 沈濃縮法を，また担体鉄その他妨害元素との分離には，Dowex 50WX8 を用いるイオン交換分離法を 用いた. 分離したセレンを 2,3 -ジアミノナフタレンと反応させ，生成した 4,5-ベンゾピアセレノール をシクロへキサンで抽出し，けい光定量すると $90 \%$ 以上の回収率で微量のセレンが分離定:量できた. 本法により大阪府岬町，和歌山県湯浅町，同浦神湾で採取した海水中のセレンを定量し $0.01 \sim 0.07$ $\mu \mathrm{g} / l$ という值を得た。
\end{abstract}

\section{1 緒可}

従来, 海水中のセレン量については $4 \sim 6 \mu \mathrm{g} / l$ と比較 的高い值が与えられていたが1)2)，最近では 0.5〜0.08 $\mu \mathrm{g} / l$ という值が提出されている3/4). 一般に海水中のセ レン量は沿岸の特定海域を除けばその存在量はきわめて 微量であると考えられる. またセレンの海水中での溶存 状態については，そのほとんどが巠セレン酸として存在 するとの指摘3) がある以外詳細な報告はない。

著者らは海水中のセレン量ならびにその存在状態を知 る目的で，これに適した微量セレンの精確な定量法を確 立する目的で研究を行なった. 一般に微量セレンの分析 には芳香族ジアミン類を用いる吸光光度法, けい光法が 用いられている. 有吉ら5) は 3,3'-ジアミノベンチジン およびオルトフェニレンジアミンを用いるセレンの吸光

* 近畿大学理工学部化学教室 : 大阪府東大阪市小若江 321

** 京都大学化学研究所 : 京都府宇治市五ケ庄
光度法を確立した．また Parker ら6)は微菓セレンのけ い光定量試薬としてオルトフェニレンジアミン, 1, 2- あ るいは 2,3-ジアミノナフタレンが有効であることを明 らかにした. Cuker ら゙) 2,3-ジアミノナフタレンを 用いて植物中のセレンをけい光定量する方法を案出し， 同位体希䣋法を併用して該法によるセレンの回収率を求 めている. さらに Chau ら) は 3,3'-ジアミノベンチジ ンを用いて海水中のセレンを吸光光度定量した。これら の報告はいずれも芳香族のオルトジアミン類を用いてセ レンをピアセレノールとし，吸光光度法あるいはけい光 法により䇥量している。これらの諸法のうれ 2,3-ジア ミノナフタレンによるけい光法が感度, 精度の点で鼠も すぐれているようである. しかし 2,3-ジアミノナフタ レンを用いてセレンをけい光定量するとき，使用試薬 の精製，定量条件の選定によって精度が大きく左右され る. そこで本試薬によるセレンのけい光定量法の基礎的 条件を詳細に検討するとともに，該法を用いた海水中の セレンの分析法を検討，確立した。 


\section{2 試楽および装置}

\section{1 試 薬}

2,3-ジフミノナフタレン(DAN) の精製と溶液 $(0.1 \%)$ の調製：東京化成 KK 製 DAN を次の方法により精製 して使用した. $1 \mathrm{~g}$ の DANを $20 \mathrm{~m} l$ のエタノールに加 温溶解, 沪過する. 沪液を約 $-20^{\circ} \mathrm{C}$ に冷却, 析出物を 吸引沪過し， $50 \%$ 冷ェタノールでじゅうぶえ洗浄する。 得られた絬晶を冷喑所で乾燥し， $-20^{\circ} \mathrm{C}$ 以下の暗所に 保存する.このようにして精製したDAN $0.1 \mathrm{~g}$ をとり， 塩酸ヒドロキシルアミン $0.5 \mathrm{~g}$ を加兄, $0.1 N$ 塩酸 100 $\mathrm{m} l$ を用いて $50^{\circ} \mathrm{C}$ で 20 分間加温溶解寸る. 泠却後 $10 \mathrm{~m} l$ のデカリンで 3 回ずつ抽出し不純物を除き, 水溶 液を $-20^{\circ} \mathrm{G}$ で氷結させる。. これを徐々に溶解し, 表面 に遊離したデカリンを除去し, 冷暗所に保存する.この ようにして調製したDAN 溶液は冷暗所に保存しておけ ば約 1 カ月法使用できるが，できるだけ新しく調製した ものを使用するほうが安全である。

セレン(IV) 標準溶液: 亜セレン酸 $\mathrm{H}_{2} \mathrm{SeO}_{3} 0.1633 \mathrm{~g}$ をとり, 水に溶解し全容 $100 \mathrm{~m} l$ とし, $1 \mathrm{mg} \mathrm{Se} / \mathrm{ml}$ 溶 液を調製した。これを適当に希䣋して使用した.

${ }^{75} \mathrm{Se}$ 溶液: 英国 Amersham の Radiochemical Center より輸入した ${ }^{75} \mathrm{Se}\left(5.4 \mathrm{mC} / \mathrm{mg} \mathrm{Se}, \mathrm{Na}_{2} \mathrm{SeO}_{3}\right.$ 水溶液) を水で希釈し約 $1 \mu \mathrm{c} / \mathrm{m} l$ として使用した.

ウラニン標準溶液 $: 0.5 \mu \mathrm{g}$ ウラニン $/ \mathrm{m} l$ および 0.0625 $\mu \mathrm{g}$ ウラニン $/ \mathrm{ml}$ 水溶液を調製し, けい光計のせッティ ングのための対照溶液として使用した。

その他の試薬はすべて特級品を用いた。

\section{2 装}

けい光スペクトルおよびけい光強度の測定には日立製 分光けい光光度計 MPF-2A 型, 同 203 型ならびに同 社製 EPU-2A 型分光光度計に G-3 けい光分光付属装 置を組み合わせたもの（光源：ともに $150 \mathrm{~W}$ ーキセノン ランプ使用）を適宜用いた. $\mathrm{pH}$ の測定には日立-堀場

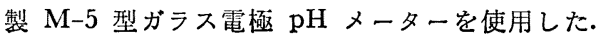

また放射能の測定は, 神戸工業製ウェル型シンチレー ションカウンタ $\left\{13 / 4^{\prime} \times 2^{\prime} \mathrm{NaI}(\mathrm{Tl})\right.$ クリスタル付きシン チレーションプローブ PS 300 トランジスタースケーラ - 5A 230\}によった.

\section{3 実験および結果}

\subsection{DAN によるセレンのけい光定量}

セレン (IV) は弱塩酸酸性で DAN と反応して 4,5-ベ ンゾピアセレノールを生成し，トルエン，デカリンなど の有機溶媒に抽出され, 紫外線照射により緑黄色のけい 光を発する。<smiles>Nc1cc2ccccc2cc1N</smiles>
2,3-diaminonaphthalene 4,5-benzopiazselnol

このけい光反応を利用した 4 価のセレンのけい光定量
法の各種条件について検討した.

3.1.1 励起およびけい光スペクトル 4, 5-ピアセレ ノールのトルエン, シクロヘキサン溶媒の励起およびけ い光スペクトルを Fig. 1 に示した. 4,5-ピアセレノー ルは抽出溶媒の種類により励起, けい光スペクトルが若 干移動する・すなわちトルエン溶媒中では励起，けい光 極大波長はそれぞれ $380 \mathrm{~nm} ， 538 \mathrm{~nm}$ に，またシクロ ヘキサン溶媒のそれは $375 \mathrm{~nm}, 520 \mathrm{~nm}$ にあり，トルエ ン溶媒の両スペクトルの極大波長はシクロヘキサン溶媒 の両極大波長より長波長側に移動している. 2,3-ジアミ ノナフタレン試薬のシクロヘキサン溶媒における励起, けい光スペクトルを求めたところ $300 〜 305 \mathrm{~nm}$ に励起 極大波長, $500 \mathrm{~nm}$ にけい光極大波長を有するが，じゅ うぶん精製された新調の本試薬のけい光はきわめて微弱 であり，かつ 4,5-ピアセレノール 錯体の励起，けい光 極大波長と大きく異なるので，じゅうぶんスペクトルを 分離測定することが可能である.

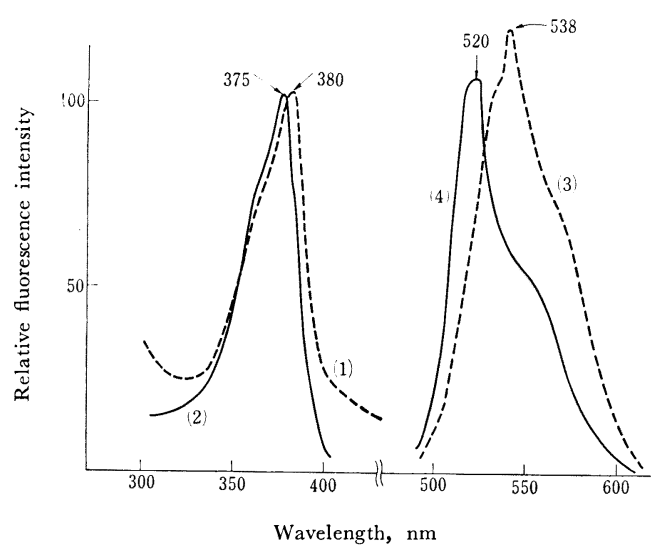

Fig. 1 Excitation and emission spectra of 4,5benzopiazselenol complex (uncollected spectra, by using Hitachi MPF-2A spectrofluorometer)

(1) Excitation spectrum of 4,5-benzopiazselenol in toluene, emission spectrum measured at $538 \mathrm{~nm}$; (2) Excitation spectrum of 4,5-benzopiazselenol in cyclohexane, emission spectrum measured at $520 \mathrm{~nm}$; (3) Emission spectrum of 4,5-benzopiazselenol in toluene; (4) Emission spectrum of 4,5-benzopiazselenol in cyclohexane

3.1.2 pH の影響 セレン(IV) $0.5 \mu \mathrm{g}$ に $0.1 M$ エチレンジアミン 四酶酸溶液 $0.5 \mathrm{ml}, 0.1 M$ フッ化ナ トリウム溶液 $0.5 \mathrm{~m} l$ および $0.1 \% \mathrm{DAN}$ 溶液 $10 \mathrm{~m} l$

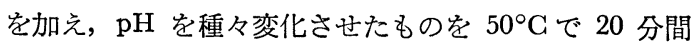
加温, 冷却後シクロヘキサンあるいはトルェン $10 \mathrm{ml}$ で 
抽出する. 抽出有機溶媒相のけい光強度を測定して, $\mathrm{pH}$ とけい光強度との関係を求めた結果を Fig. 2 に示 した。 また上記操作に従い ${ }^{75} \mathrm{Se}(\mathrm{IV})$ をトレーサーとし て求めた 4,5-ベンゾピアセレノールのトルエシ相への 抽出曲線を Fig. 2 曲線（7）に示した.

Fig. 2 曲線（7) よりわかるように，4,5-ベンゾピア セレノールは $\mathrm{pH}$ 0.7〜1.5 で 99\% 以上がトルエンに 抽出されていることを知る. 抽出溶媒にシクロへキサン を用いた場合， $\mathrm{pH} 1$ の水相より抽出すると最大けい光 強度を示す $\{$ 曲線 (3) \}. またトルエンを抽出溶媒とす るときは $\mathrm{pH}$ 0.5〜1 の水相より抽出すると一定のけい

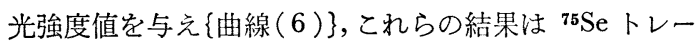
サー法の結果 $\{$ 曲線 (7) \} とよく一致している. したが って以後の実験では，水相の $\mathrm{pH} 1$ より有機溶媒で抽 出することにした.

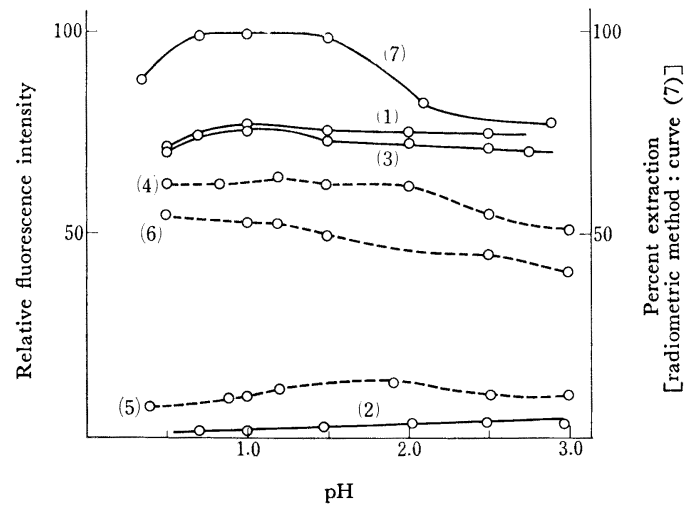

Fig. 2 Effect of $\mathrm{pH}$ of solution on fluorescence intensity (Extraction curves of 4,5-benzopiazselenol with cyclohexane or toluene by using Hitachi 203 spectrofluorometer)

(1) $0.5 \mu \mathrm{g} \mathrm{Se}, 0.1 \% \mathrm{DAN} 10 \mathrm{~m} l$, cyclohexane $10 \mathrm{~m} l$, fluorometer readings were setted at $80 \mathrm{div}$. with $0.5 \mu \mathrm{g}$ uranine/ml reference solution; (2) Reagent blank, $0.1 \%$ DAN $10 \mathrm{~m} l$, cyclohexane $10 \mathrm{~m} l, 80$ div.; (3) Subtracted the reagent blank value of curve (2) from the fluorescence intensity of curve (1); (4) $0.5 \mu \mathrm{g}$ Se, $0.1 \%$ DAN $10 \mathrm{ml}$, toluene $10 \mathrm{ml}, 70$ div.; (5) Reagent blank, $0.1 \%$ DAN $10 \mathrm{~m} l$, toluene $10 \mathrm{~m} l, 70$ div.; (6) Subtracted the reagent blank value of curve (5) from the fluorescence intensity of curve (4); (7) ${ }^{75} \mathrm{Se}(30000 \mathrm{cpm})$, Se carrier $10 \mu \mathrm{g} 0.1 \%$ DAN $10 \mathrm{ml}$, toluene $10 \mathrm{ml}$ (radiometric method)

3.1.3 試薬量の影響 セレン一定量をとり, 試薬の 添加量を変え, $\mathrm{pH} 1$ よりシクロヘキサンあるいはトル エン抽出を行ない試薬量とけい光強度との関係を求め た結果を Fig. 3 に示す. $0.5 \mu \mathrm{g}$ までのセレンに対し,
$0.1 \% \mathrm{DAN}$ 水溶液 $10 \mathrm{~m} l$ 加えればじゅうぶえである. また $0.05 \mu \mathrm{g}$ までのセレンに対しては，0.1\% DAN 水 溶液 $3 \mathrm{ml}$ 使用すればじゅうぶえであった. DAN 試薬 はその使用量とともに試薬ブランク值はやや上昇する傾 向にある.したがって以後の実験では $0.05 \mu \mathrm{g}$ までの セレンに対しては $0.1 \% \mathrm{DAN}$ 水溶液 $5 \mathrm{ml}$ を，また $0.5 \mu \mathrm{g}$ までのセレンに対しては $0.1 \% \mathrm{DAN}$ 水溶液 10 $\mathrm{ml}$ を加え，その試薬ブランク值を差し引くことにした。

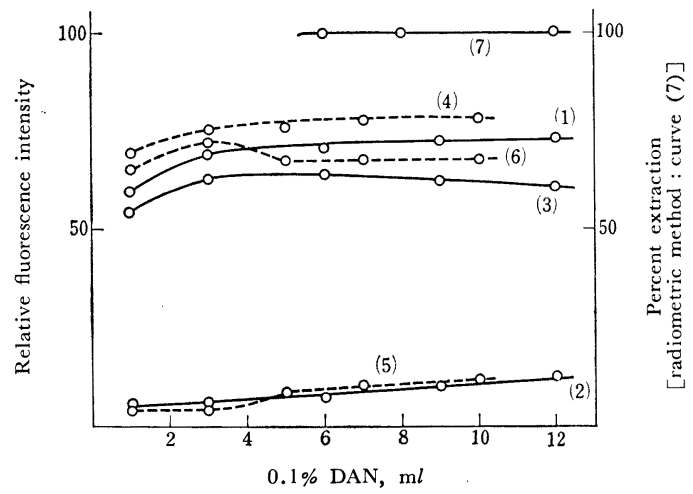

Fig. 3 Effect of reagent concentration on fluorescence intensity (Hitachi 203 spectrofluorometer)

(1) $0.5 \mu \mathrm{g} \mathrm{Se}, \mathrm{pH} 1$, toluene $10 \mathrm{ml}, 380 \mathrm{~nm} / 538 \mathrm{~nm}$, fluorometer readings were setted at $80 \mathrm{div}$. with $0.5 \mu \mathrm{g}$ uranine/ml reference solution; (2) Reagent blank, $\mathrm{pH} \mathrm{1,} \mathrm{toluene} 10 \mathrm{ml}, 80 \mathrm{div}$; (3) Subtracted the reagent blank value of curve (2) from the fluorescence intensity of curve (1); (4) $0.05 \mu \mathrm{g} \mathrm{Se}, \mathrm{pH} \mathrm{1}$, cyclohexane $10 \mathrm{~m} l, 375 \mathrm{~nm} / 520 \mathrm{~nm}$, fluorometer readings were setted at $80 \mathrm{div}$. with $0.0625 \mu \mathrm{g}$ uranine $/ \mathrm{ml}$ reference solution; (5) Reagent blank, pH 1, cyclohexane $10 \mathrm{ml}, 80 \mathrm{div}$; (6) Subtracted the reagent blank value of curve (5) from the fluorescence intensity of curve (4); (7) Radiometric method

なお， ${ }^{75} \mathrm{Se}$ をトレーサー (carrier $\left.1 \mu \mathrm{g} \mathrm{Se}\right)$ として 試薬量と 4,5-ベンゾピアセレノールのトルエンへの抽 出率を求めた結果は Fig. 3 曲線 (7) に示すと扬りであ り，1 $1 \mu \mathrm{g}$ のセレンに対し $0.1 \% \mathrm{DAN}$ 水溶液 $6 \mathrm{ml}$ 以 上使用したとき $99 \%$ 以上の抽出率でトルェンに抽出さ れていることを知った.

3.1.4 反応温度の影響 セレン $(\mathrm{IV})$ と DAN の 反応は抢そく, 反応温度 $13 \sim 20^{\circ} \mathrm{C}$ で放置時間とともに けい光強度が徐々に増加するが，2 時間後においても $50^{\circ} \mathrm{C}, 20$ 分加温反応溶液が示す最大けい光強度の大約 $1 / 2$ のけい光強度を示すにすぎない. 抽出前の反応溶液 の温度, 反応時間とけい光強度の関係をセレン $0.5 \mu \mathrm{g}$, $0.1 \% \mathrm{DAN}$ 水溶液 $10 \mathrm{ml}, \mathrm{pH} 1$ の反応溶液について 
調査した結果を Fig. 4 に示す. Fig. 4 に示すように， 反応温度 $80^{\circ} \mathrm{C}$ 以上では $10 \sim 20$ 分間加温で一定の最大 けい光強度を示すが，長時間加温するとかえってけい光 強度の減少を示す. $50^{\circ} \mathrm{C}$ 加温では $80^{\circ} \mathrm{C}$ 加温に比べ, 最大けい光強度到達時間はややおそくなるが，20～60 分 の間では一定のけい光強度を示す. したがって抽出前 の反応条件を $50^{\circ} \mathrm{C} ， 20$ 分加温とした。 この条件では DAN 試薬，4,5-ベンゾピアセレノール錯体ともに安定 でけい光強度も一定の最大けい光強度を示す.

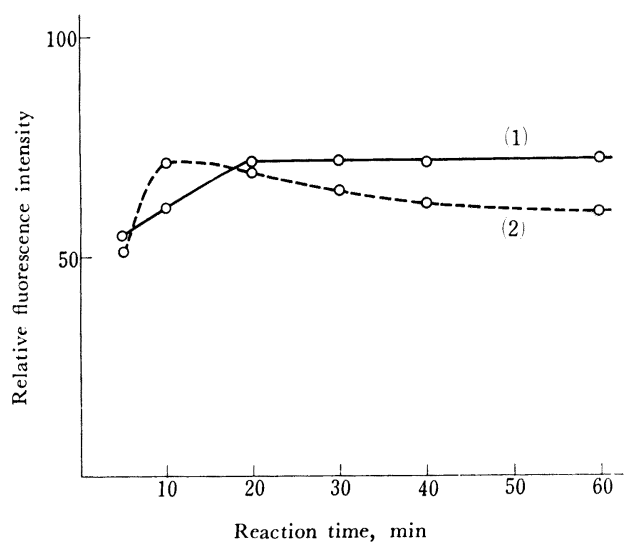

Fig. 4 Effect of reaction time

(1) $\mathrm{Se} 0.5 \mu \mathrm{g}, 0.1 \% \mathrm{DAN} 10 \mathrm{ml}$, reaction temp. $50^{\circ} \mathrm{C}$, toluene $10 \mathrm{ml}, 380 \mathrm{~nm} / 538 \mathrm{~nm}$, fluorometer readings were setted at $80 \mathrm{div}$. with $0.5 \mu \mathrm{g}$ uranine $/ \mathrm{ml}$ reference solution (Hitachi 203 spectrofluorometer); (2) Se $0.5 \mu \mathrm{g}, 0.1 \%$ DAN $10 \mathrm{ml}$, reaction temp. $80^{\circ} \mathrm{C}$, toluene $10 \mathrm{~m} l, 380 \mathrm{~nm} / 538 \mathrm{~nm}, 80 \mathrm{div}$. (Hitachi 203 spectrofluorometer)

反応後の有機溶媒による抽出時の振り混ぜ時間と抽出 率との関係を ${ }^{75} \mathrm{Se}$ をトレーサーとして検討したところ， 5 分間以上振り混ぜれば抽出平衡に達することを知っ た。

3.1.5けい光強度の経時変化 4,5-ベンゾピアセレ ノールはトルエン，デカリン，シクロヘキサン，クロロ ホルムなどの 有機溶媒に抽出され, けい光を発する. ${ }^{75} \mathrm{Se}$ をトレーサーとしてこれら有機溶媒による錯体の抽 出率を検討したところ，いずれも $90 \%$ 以上の抽出率を 有し，抽出溶媒としてすぐれている．しかしクロロホル ムを溶媒とするときクロロホルム相が淡黄色を呈し, け い光強度が若干低下した. トルエン，デカリンはシクロ ヘキサンを抽出溶媒とする場合に比べ, 試薬ブランクの けい光強度が若干高い \{Fig. 2 曲線 (2)，(5)\}. したが って試薬ブランクのけい光值を考虑するとシクロヘキサ ンが抽出溶媒としてすぐれている.
シクロヘキサン，トルエン溶媒における 4,5-ベンゾ ピアセレノールのけい光の 経時変化を測定した結果を Fig. 5 に示した. Fig. 5 よりわかるように, 本錯体はシ クロヘキサン, トルエン溶媒中では強い紫外線に暴露し ないかぎりいずれも 2 時間まではけい光強度に変化なく 安定であった.

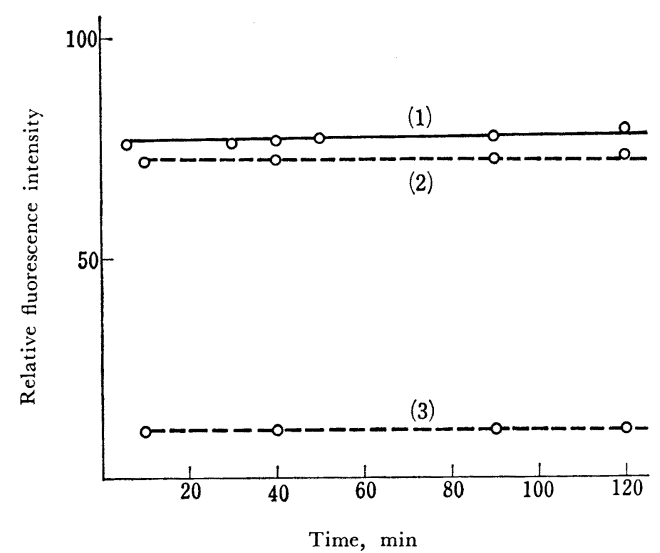

Fig. 5 Stability of fluorescence intensity of 4,5benzopiazselenol complex (Hitachi 203 spectrofluorometer)

(1) Se $0.5 \mu \mathrm{g}, 0.1 \% \mathrm{DAN} 10 \mathrm{~m} l$, cyclohexane $10 \mathrm{~m} l$, $375 \mathrm{~nm} / 520 \mathrm{~nm}, 80$ div. vs. $0.5 \mu \mathrm{g}$ uranine $/ \mathrm{ml}$; (2) Se $0.5 \mu \mathrm{g}, 0.1 \%$ DAN $10 \mathrm{~m} l$, toluene $10 \mathrm{ml}, 380 \mathrm{~nm} /$ $538 \mathrm{~nm}, 80$ div. vs. $0.5 \mu \mathrm{g}$ uranine $/ \mathrm{ml}$; (3) Reagent blank, $0.1 \%$ DAN $10 \mathrm{~m} l, 380 \mathrm{~nm} / 538 \mathrm{~nm}, 80$ div. $v s$. $0.5 \mu$ uranine $/ \mathrm{m} l$

3.1.6 セレンのけい光定量 以上の諸条件の検討の 結果を基にすれば，セレンは次のように操作するとき正 確に定量できる.

$0.1 \sim 1 \mu \mathrm{g}$ のセレンを含む試料溶液 $5 \mathrm{ml}$ に $0.1 \%$ $\mathrm{DAN}$ 水溶液 $10 \mathrm{ml}$ (セレン $0.1 \mu \mathrm{g}$ 以下の低濃度試料溶 液については $0.1 \% \mathrm{DAN}$ 水溶液 $5 \mathrm{~m} l$ ) を加え, 鉄の いえペい剤として $0.1 M$ EDTA 水溶液 $0.5 \mathrm{ml}, 0.1 M$ フッ化ナトリウム溶液 $0.5 \mathrm{ml}$ を加え, 塩酸あるいはア ンモニア水で $\mathrm{pH}$ を 1 に調節し, 全容約 $25 \mathrm{ml}$ とする. 水浴上で $50^{\circ} \mathrm{G}$ に 20 分間加温後, 流水中で泠却し, ト ルエンあるいはシクロヘキサン $10 \mathrm{~m} l$ を用いて 5 分間振 り混ぜ抽出する. 水相を分離除去後, 有機相を遠心分離 機 $(2000 \mathrm{rpm})$ で遠心脱水後, ウラニン標準溶液を対照 としてけい光強度を測定する. Fig. 6 に日立けい光分光 光度計 G-3 型, 203 型および MPF-2A 型を用いて求 めた検量線の 1 例を示した. 本法により $0.1 〜 1 \mu \mathrm{g}$ の セレンについては $0.5 \mu \mathrm{g}$ ウラニン $/ \mathrm{m} l$ 標準溶液を対照 
にまた 0.01〜0.1 $\mu \mathrm{g}$ のセレンについては $0.0625 \mu \mathrm{g}$ ウラニン $/ \mathrm{m} l$ 標準溶液を対照にけい光強度を測定すれば 誤差 $\pm 2 \%$ 以内で正確にセレンが定量できる.

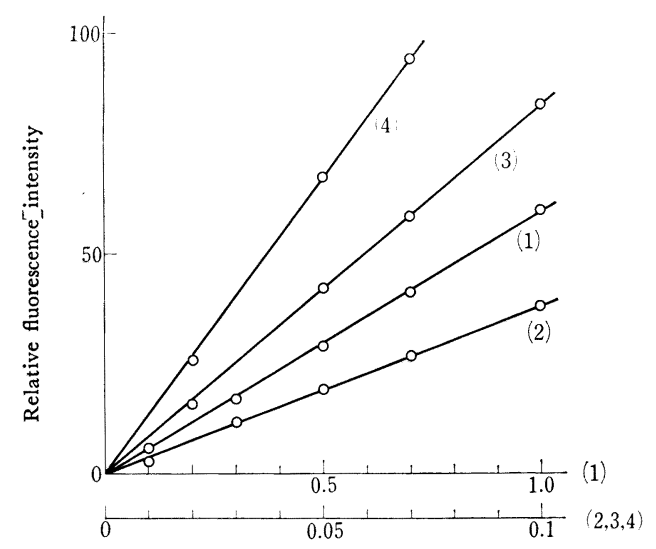

Fig. 6 Analytical curves for selenium

(1) 50 div. with $0.5 \mu \mathrm{g}$ uranine $/ \mathrm{m} l$ reference solution, toluene system, $380 \mathrm{~nm} / 538 \mathrm{~nm}$ (Hitachi G-3 spectrofluorometer); (2) $70 \mathrm{div}$. with $0.0625 \mu \mathrm{g}$ uranine $/ \mathrm{ml}$ reference solution, toluene system, $380 \mathrm{~nm} / 538 \mathrm{~nm}$ (Hitachi MPF-2A spectrofluorometer); (3) 50 div. with $0.0625 \mu \mathrm{g}$ uranine $/ \mathrm{m} l$ reference solution, cyclohexane system, $375 \mathrm{~nm} / 520 \mathrm{~nm}$ (Hitachi 203 spectrofluorometer); (4) 80 div. with $0.0625 \mu \mathrm{g}$ uranine $/ \mathrm{m} l$ reference solution, cyclohexane, $375 \mathrm{~nm} / 520 \mathrm{~nm}$ (Hitachi 203 spectrofluorometer)

本操作によるときセレンに対し 100 倍量のコバルト (II), マンガン(II), 硝酸イオン, 亜硝酸イオンが共存 すると負誤差を与え妨害する．鉄(III) イオンの少量は EDTA，フッ化ナトリウムをいえぺい率として添加して おけばその影響より免れるが，セレン数 $\mu \mathrm{g}$ に対し $1 \mathrm{mg}$ 以上の鉄が共存すると負誤差を与え妨害する.カドるウ ム, 亜鉛, ニッケル, アルミニウム, クロム(III), セ リウム(IV), チタン $(\mathrm{IV})$, モリブテン $(\mathrm{VI})$, 硫酸イオ ンタシュウ酸イオンはセレンに対し 100 倍以上共存して も影響しない.

\section{4 海水中のセレンの定量}

前項に示したように本けい光法ではコバルト，亜鉛， 硝酸イオンなどが妨害する.したがってこれらのイオン と共存するセレンはあらかじめ適当な方法で分離しなけ ればならない：また海水中のセレンはきわめて微量であ るので濃縮する必要がある。そこで濃縮には水酸化鉄を 担体とする共沈濃縮法を，また担体として用いた鉄の除 去には陽イオン交換分離法を適用した。

\section{1 セレンの共沈濃縮}

海水中のセレン $(\mathrm{IV})$ を濃縮するため水酸化鉄による 共沈濃縮法を用いた。共沈率の測定は ${ }^{75} \mathrm{Se}$ をトレーサ とする方法によった・すなわちあらかじめ䘏酸を添加し て微酸性とした海水 $1 l$ に ${ }^{75} \mathrm{Se}$ 一定量, 鉄(III) $10 \mathrm{mg}$ を加光，アンモニア水で $\mathrm{pH}$ を調節して水酸化鉄を沈殿 させる.上澄液の放射能を測定してセレン共沈率を求め た結果を Fig. 7 に示した. Fig. 7 よりわかるように， 水酸化鉄を $\mathrm{pH} 2.8$ ～より沈殿させるとセレンの $95 \%$ 以上が共沈した*。

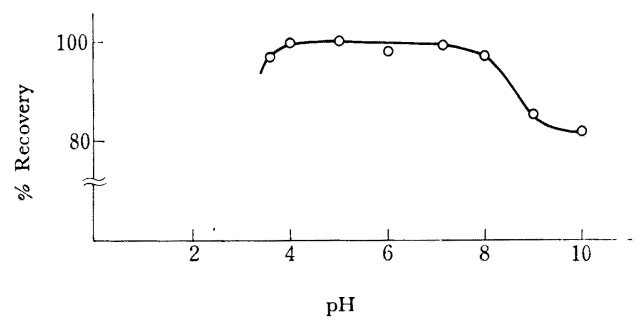

Fig. 7 Coprecipitation of selenium(IV) with ferric hydroxide

\section{2 セレンのイオン交換分離}

水酸化鉄と共沈したセレンを担体鉄などから分埕した のち前記の DAN けい光法で定量する場合の分離法とし てイオン交換分離法を用いた. セレンのイオン交換分離 については吉野8) の研究があり, 微量のセレンの分離に この方法を用いることを検討した。

イオン交換樹脂は, Dowex 50 WX8 (H型) を $\phi$ : $30 \mathrm{~mm}$ ，高さ $50 \mathrm{~mm}$ のカラムとして用いた。

鉄 $5 \mathrm{mg}$ と ${ }^{75} \mathrm{Se}$ (carrier Se $0.4 \mu \mathrm{g}$ を含む) を含む

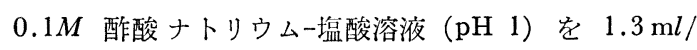
$\min$ の速さでイオン交換樹脂柱を通し鉄を吸着させ 0.1 $M$ 酶酸ナトリウム溶液（pH 1) でセレンを溶離する. 流出液を $1 \sim 5 \mathrm{~m} l$ ごとに分けてとり，各部分について 放射能強度を測定しセレンの溶出曲線を求めた．との結 果は Fig. 8 に示すように 10～100 $\mathrm{ml}$ の間で完全に流出 し，セレンを回収できる.一方，この容量の $0.1 M$ 酶酸 ナトリウム溶離液では鉄はまったく溶出しないのでセレ ンとの分離は完全である.

\section{3 海水中のセレンの定量}

前項をでの諸条件の検討結果より海水中のセレンを次

* 七レン(VI) はこの pH 領域では水酸化鉄にはほと えぞ共沈しない。 


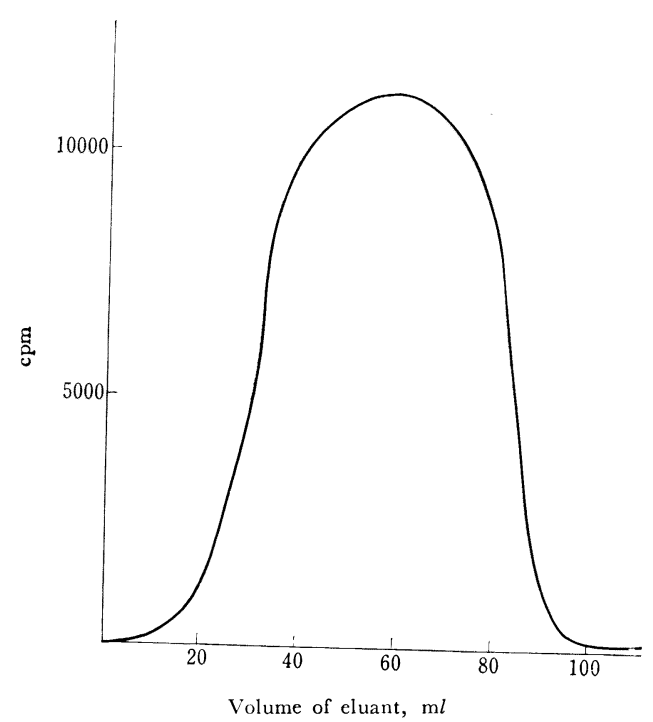

Fig. 8 Separation of selenium by ion exchange column

Column : Dowex $50 \mathrm{WX8}$ (H-form) : $30 \mathrm{~mm}$, hight : $50 \mathrm{~mm}$, flow rate $: 1.3 \mathrm{ml} / \mathrm{min}$; Conditioning : (1) $4 \mathrm{~N}$ HCl $100 \mathrm{ml}$, (2) $\mathrm{H}_{2} \mathrm{O} 50 \mathrm{ml}$, (3) $2 N \mathrm{NaCl} 100 \mathrm{~m} l$, (4) $\mathrm{H}_{2} \mathrm{O} 50 \mathrm{ml}$; Fluant : $0.1 M$ sodium acetate solution ( $\mathrm{pH}$, adjusted with $\mathrm{HCl}$ )

\section{のようにして定量した・}

海水試料 はあらかじめ $0.1 N$ 䘏酸酸性とし, 試料水 $5 l$ に対して鉄(III) イオン $30 \mathrm{mg}$ を加穴, アンモニア 水で $\mathrm{pH}$ を 5.5 とし水酸化鉄を沈殿させる*. 1 夜放 置後, 東洋沪紙 No. 5 A で吸引沪過し, 沈殿をよく水 洗する. 沈殿を $2.5 \sim 3.0 \mathrm{ml}$ の塩酸に 溶解し，これに $1 M$ 酶酸ナトリウム溶液の計算量を加え, $0.1 M$ 酶酸ナ トリウム， $\mathrm{pH} 1$ とし全容 $25 \sim 30 \mathrm{ml}$ の溶液とする. この溶液を前記 Dowex 50 のカラムに $1.3 \mathrm{ml} / \mathrm{min} の$ 速度で通し吸着させたのち， $0.1 M$ 酢酸ナトリウム溶液 （pH 1 に調節）で溶離する. 流出液 $10 \sim 100 \mathrm{ml}$ 部分 を採取し，これを蒝発濃縮したものについて 3.1 .6 の操 作に従いセレンを定量する.

人工海水 $1 l$ を用いてこの操作に従ってセレンを定量 した結果を Table I に示した. 本法により $90 \%$ 以上 の回収率で定量が可能である.

本操作により数種の海水, 河川水試料についてセレン の定量を行なった. その結果を Table II に示した.

Table II 中試料番号 1，2，3，4，7 は全セレン量を求 めた結果を，また試料番号 $5 ， 6 ， 8$ は試料採取後ただ

* 鉄 $30 \mathrm{mg}$ を $20,5,5 \mathrm{mg}$ と 3 回に分けて添加沈殿 させる.
Table I Determination of selenium in artificial sea-water

\begin{tabular}{ccccccc}
\hline No. & $\begin{array}{c}\text { Se } \\
\text { added } \\
(\mu \mathrm{g})\end{array}$ & $\begin{array}{c}\mathrm{Fe}^{3+} \\
\text { added } \\
(\mu \mathrm{g})\end{array}$ & $\begin{array}{c}\text { Eluant } \\
\text { taken } \\
(\mathrm{m} l)\end{array}$ & $\begin{array}{c}\text { Aliquot of } \\
\text { eluant taken } \\
(\mathrm{m} l)\end{array}$ & $\begin{array}{c}\mathrm{Se} \\
\text { found } \\
(\mu \mathrm{g})\end{array}$ & $\begin{array}{c}\text { Recovery } \\
(\%)\end{array}$ \\
\hline 1 & 2.0 & 26 & 100 & 10 & $0.22_{5}$ & 112.5 \\
2 & 1.0 & 13 & 100 & 10 & 0.10 & 100 \\
& & & & 50 & 0.46 & 92 \\
3 & 5.0 & 13 & 100 & 10 & 0.46 & 92 \\
& & & & 20 & 1.04 & 104 \\
\hline
\end{tabular}

Table II Analysis of selenium in sea water and river water

\begin{tabular}{|c|c|c|}
\hline No. & Sample & $\begin{array}{l}\text { Selenium(IV) in natural } \\
\text { water }(\mu \mathrm{g} / l)\end{array}$ \\
\hline 1 & $\begin{array}{l}\text { Offshore of Misaki, Osaka pref., } \\
\text { (Dec. 22th, 1970) Sample A }\end{array}$ & 0.05 \\
\hline 2 & $\begin{array}{l}\text { Offshore of Misaki, Osaka pref., } \\
\text { (Dec. 22th, 1970) Sample B }\end{array}$ & 0.07 \\
\hline 3 & $\begin{array}{l}\text { Seashore of Yuasa, Wakayama pref., } \\
\text { (Feb. 13th, 1971) Sample A }\end{array}$ & 0.04 \\
\hline 4 & $\begin{array}{l}\text { Seashore of Yuasa, Wakayama pref., } \\
\text { (Feb. 13th, 1971) Sample B }\end{array}$ & 0.02 \\
\hline 5 & $\begin{array}{l}\text { Offshore of Uragami, Wakayama } \\
\text { pref., (July 19th, 1971) }\end{array}$ & $\left.\begin{array}{l}8 \mu \cdots \cdots \cdots 0.01_{4} \\
\text { filtrate } \cdots 0.03_{5}\end{array}\right\} 0.04_{9}$ \\
\hline 6 & $\begin{array}{l}\text { Offshore of Uragami, Wakayama } \\
\text { pref., (May 2nd, 1972) }\end{array}$ & 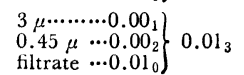 \\
\hline 7 & $\begin{array}{l}\text { Mauth of river Hidaka Wakayama } \\
\text { pref., (Jun. 21th, 1971) }\end{array}$ & 0.10 \\
\hline 8 & $\begin{array}{l}\text { Lake Biwa, Shiga pref., } \\
\text { (Jun. 10th, 1972) }\end{array}$ & $\left.\begin{array}{lll}0.45 \mu & \cdots 0.00_{4} \\
\text { filtrate } & \cdots 0.01_{7}\end{array}\right\} 0.02_{1}$ \\
\hline
\end{tabular}

ちにミリポァフィルター（平均有効沪過半径 $8,3,0.45$ $\mu$ ）で浮遊懸濁粒子を分画した場合のフィルターおよび 沪液中のセレン量を示したものである.

Table II に示したように, 海水中のセレン含量は 0.01 $\sim 0.07 \mu \mathrm{g} / l$ という結果が得られたが，乙れは Schutz ら の放射化分析の結果とほぼ同程度であった. また試料番 号 5,6 の結果のように海水中ではセレンは浮遊懸濁物 質に占める割合よりも沪液中の可溶性な状態の占める割 合のほうが多いようである.

河川水，湖水など陸水中のセレンについては 2 例の分 析結果ではあるが， $0.02 \sim 0.1 \mu \mathrm{g} / l$ とその含有量には 大きな差があり，地域的な变動が大きいようである.

これら海水, 河川水, 湖水中の七レン含量については 多数の試料の分析結果について地球化学的な考察をする 必要があり, 目下各地で採取した多数の試料について検 討中である. また，本報告に抢ける天然水中のセレンの 分析法は 4 価のセレンに適用できるものであり, 別に 6 価のセレンの共沈濃縮, 分離, 定量法についても検討 し，信頼しうる分析法を得ているが，これらについては あらためて報告する・ 


\section{文献}

1) H. Wattenberg : Z. anorg. Chem., 236, 339 (1938).

2) M. Ishibashi, T. Shigematsu, Y. Nishikawa : Record. Ocean. Wark. Japan, 1, 44 (1953).

3) Y. K. Chau, J. P. Riley : Anal. Chim. Acta, 33, 36 (1965).

4) D. F. Schutz, K. K. Turekian : Geochim. Cosmochim. Acta, 29, 259 (1965).

5) H. Ariyoshi, M. Kiniwa, K. Toei : Talanta, 5, 1121 (1960).

6) G. A. Parker, L. G. Harney : Analyst, 87, 558 (1962).

7) P. Cuker, J. Walzcyk, P. Lott : Anal. Chim. Acta, 30, 473 (1964).

8) 吉野諭吉：日化， 71, 577 (1950).

$$
\text { is }
$$

Fluorometric determination of selenium in sea-water. Keizō Hiraki, Osamu Yoshir, Hiroshi Hirayama, Yasuharu Nishikawa* and Tsunenobu Shigematsu** (*Department of Chemistry, Faculty of Science and Engineering, Kinki University, 321, Kowakae, Higashiosaka-shi, Osaka; **Institute for Chemical Research, Kyoto University, Gokanosho, Uji-shi, Kyoto)

2,3-Diaminonaphthalene reacts with selenium(IV) to form a complex with greenish yellow fluorescence, which are extracted into organic solvents, such as cyclohexane, toluene etc., and was used as a sensitive reagent for the fluorometric determination of selenium. The authors have studied on the fluorometry of selenium with the reagent, and the method was adopted for analysis of selenium in sea-water.

Fifty milliliters of conc. $\mathrm{HCl}$ and $20 \mathrm{mg}$ of $\mathrm{Fe}^{3+}$ as
$\mathrm{FeCl}_{3}$ solution were added to $5 l$ of sample sea-water, and $\mathrm{pH}$ of the solution was adjusted to 5.5 with ammonia. After a few hours $5 \mathrm{mg}$ of $\mathrm{Fe}^{3+}$ and ammonia were added to the solution. This procedure was repeated. After being allowed to stand overnight, the precipitate was filtered and washed with water, then dissolved in $5 \sim 6 \mathrm{ml}$ of $6 \mathrm{~N} \mathrm{HCl}$. Three milliliters of $1 \mathrm{M}$ sodium acetate solution was added to the solution and $\mathrm{pH}$ was adjusted to 1 by adding conc. $\mathrm{HCl}$, and the total volume was made up to $30 \mathrm{ml}$. To remove $\mathrm{Fe}^{3+}$, the solution was poured into an ion-exchange colume [Dowex $50 \mathrm{WX} 8$ (H-form), $\phi: 30 \mathrm{~mm}$, height: $50 \mathrm{~mm}]$, and the column was eluted with $0.1 \mathrm{M}$ sodium acetate solution ( $\mathrm{pH}$ of the solution was adjusted to 1 with hydrochloric acid, flow rate $=1.3 \mathrm{~m} l / \mathrm{min}$ ). The selenium, fraction of the eluant was evaporated to 10 $\mathrm{m} l$. Five milliliters of $0.1 \%$ 2,3-diaminonaphthalene solution, $0.5 \mathrm{ml}$ of $0.1 M$ EDTA solution, and $0.5 \mathrm{ml}$ of $0.1 M$ sodium fluoride solution were added to this solution, and $\mathrm{pH}$ of the solution was adjusted to 1 with hydrochloric acid or ammonia. The solution was diluted to $25 \mathrm{ml}$ and heated at $50^{\circ} \mathrm{C}$ for $20 \mathrm{~min}$. After being cooled to room temperature, the solution was extracted with $10 \mathrm{ml}$ of cyclohexane. The organic layer was separated and dehydrated by centrifugation, and the fluorescence intensity was measured at $520 \mathrm{~nm}$ (excitation: $375 \mathrm{~nm}$ ) against the standard uranine solution $(0.0625 \mu \mathrm{g} / \mathrm{m} l)$. In this procedure, the recovery of selenium was about $90 \%$.

Selenium contents in the sea-waters offshore of Misaki (Osaka Pref.), Yuasa and Uragami (Wakayama Pref.) were found to be $0.01 \sim 0.07 \mu \mathrm{g} / l$. The amounts of dissolved selenium and the particle size distribution of selenium in suspended matter were determined successfully by the present procedure.

(Keceived Nov. 7, 1972) 